\title{
CEO's International Characteristics and Corporate Social Responsibility
}

\author{
Muhammad Faisal \\ Department of Accounting, \\ Faculty of Economics and Business \\ Universitas Indonesia \\ Indonesia \\ m.fsl@yahoo.com
}

\author{
Chaerul D. Djakman \\ Department of Accounting, \\ Faculty of Economics and Business \\ Universitas Indonesia \\ Indonesia \\ cdjakman@gmail.com
}

\author{
Desi Adhariani* \\ Department of Accounting, \\ Faculty of Economics and Business \\ Universitas Indonesia \\ Indonesia \\ desi.adhariani@ui.ac.id
}

\begin{abstract}
The high disclosure of corporate social responsibility (CSR) activities in overseas countries, especially in Europe and the United States, was the motivation for this study to obtain empirical evidence on whether CEOs' international characteristics influence CSR activity disclosure to firms in Indonesia. This study aims to analyze the influence of CEOs who have experience working abroad, CEOs who have educational background abroad, and CEOs who have foreign citizenship on the disclosure of CSR. The sample in this study is 139 companies in the manufacturing industry listed on Indonesia Stock Exchange in 2016. This research analyzes companies' annual reports by using a content analysis method based on the Global Reporting Initiative (GRI) G4 index. The results of this study indicate that to increase the level of CSR disclosure, companies in Indonesia can consider the international characteristics of the CEO, namely, the CEO's experience working abroad and the CEO's educational background abroad, when choosing a CEO because these factors affected CSR disclosure in Indonesia. Notably, foreign citizenship of CEOs did not affect CSR disclosure in Indonesia.
\end{abstract}

Keywords-Corporate social responsibility (CSR), CEO, experience working abroad, educational background abroad, foreign citizenship, GRI G4

\section{INTRODUCTION}

Companies no longer have responsibilities based on a single bottom line, namely, a company's value is reflected in only its financial condition. Corporate responsibility should be based on the triple bottom lines, namely, people, the planet, and profits, which means a company should also address social and environmental concerns in addition to the financial concerns. Corporations should no longer be prioritizing only their businesses' profits and financial performance and should pay more attention to and take responsibility for the environmental impact caused by their operations.

The development of corporate social responsibility (CSR) cannot be separated from the increasing social problems and environmental damage occurring in Indonesia and around the world, including deforestation, air and water pollution, climate change, and labor welfare. In response to the need for CSR, the Indonesian government issued Law No. 40 of 2007 concerning Limited Liability Companies. This law requires companies in the field or related to natural resources to carry out social and environmental responsibilities and to disclose their social and environmental activities in their annual report. With this policy, the companies' accountability related to their responsibility in a social and environmental context can be assessed by stakeholders [1].
Currently, the CSR reporting for companies in Indonesia is relatively low in level and quality most likely because of the insufficient infrastructure supporting CSR reporting. Until now, there has been no standardized CSR reporting framework for reference in preparing CSR disclosure; thus, stakeholders might consider it difficult to assess the CSR effectiveness because there are no reports that can present the impact of the company's activities on social and environmental [1]. In addition, the CSR disclosure from national companies is still low probably because of their insufficient knowledge of the importance of CSR activities for the surrounding environment and the benefit of conducting CSR activities for their own goods.

Overseas companies usually have a higher level of CSR disclosure, especially companies in Europe and the United States compared with other national companies. This high level of CSR disclosure is related to the issuance of regulations requiring companies to carry out CSR activities. For example, the implementation of the Sarbanes Oxley Act of 2002 requires company to prepare financial statements to improve CSR. Another example is the 2001New Economic Regulation Law in France, regarding a company's obligation to always disclose information on activities that will affect environmental conditions and how the company considers social aspects as a part of its activities [2].

The EU Parliament issued a resolution on March 13, 2007, called "Corporate Social Responsibility: A new partnership." This resolution demanded that the European Commission increase its obligations regarding concerns related to corporate accountability such as directors' duties, external obligations, social performance reporting, and company environment. This resolution was welcomed by various parties. Over time, it is increasingly obvious that although companies have contributed positively to world development, companies must be asked to bear more responsibility for social and environmental aspects because companies tend to focused on nurturing earnings while (though not always) disregarding social responsibility [3]

The argument that states that countries other than Indonesia, especially countries in Europe and the United States, have higher CSR disclosure was supported by a survey conducted by the Yale Center for Environmental Law and Policy (YCELP) and Yale Data-Driven Environmental Solutions Group at Yale University (Data-Driven Yale) and the Center for International Earth Science Information Network (CIESIN) at Columbia University. The survey was 
in collaboration with the Samuel Family Foundation, the McCall MacBain Foundation, and the World Economic Forum. The survey on CSR disclosure was conducted in 180 countries worldwide in 2016. The YCELP and CIESIN ranked 180 countries considered to have concerns regarding CSR activities based on 11 indicators: environmental health, water quality, water \& sanitation, health impacts, ecosystem vitality, water resources, agriculture, forests, fisheries, biodiversity \& habitat, climate \& energy.

This study shows that countries with considerable concerns about CSR activities are mostly European countries and the United States, who have all scored higher on the Environmental Performance Index (EPI Score) compared with Asian and African countries. In 2016, Indonesia, with an EPI score of 65.85 , ranked 107 out of 180 countries. However, Indonesia's ranking decreased to the position of 133 out of 180 countries in 2018, when this study was conducted. According to [4], this decrease occurred because foreign companies understand that CSR activity is not only an expense to the company but a strategic asset that provides competitive advantages and benefits to companies. These beneficial factors may not be fully understood by all companies in Indonesia; thus, the CSR disclosure is still relatively low for companies in Indonesia.

Thus, based on the study that shows a higher CSR activities disclosure level for companies outside Indonesia as stipulated above, especially companies in Europe and the United States, the author examines whether there is an association between international characteristics possessed by the CEOs and the CSR activities disclosure level for companies in Indonesia. We use Global Reporting Initiative G4 (GRI-G4) as the CSR disclosure index. Leaders in this study refer to CEOs who have international work experience, received at least part of their education abroad, and foreign citizenship.

An organization's characteristic is usually reflected by the CEO's characteristics. In this research, the international characteristics of the CEO are considered inherent and related to the phase when the CEO experienced (e.g., education, training, and citizenship) countries other than Indonesia. According to [5], as a corporate leader, the CEO plays a critical role in the company's strategic decision-making and allocation of resources. The $\mathrm{CEO}$ has a responsibility to manage the company to generate profits, but some CEOs in Indonesia still consider CSR activities as activities that do not provide benefits and only reduce a company's profit; thus, CSR disclosure for companies in Indonesia is relatively low.

Overseas companies, especially companies in Europe and the United States, usually treat CSR as a means to legitimize their companies. These companies recognize that CSR activities are not just charity or expenditure but can also maintain the company's sustainability and increase customer loyalty. When CEOs with experience working overseas are assigned to Indonesian companies, an expectation is that they will act in accordance with their work experience overseas to maintain the company's existence and disclose the CSR activities of the company they lead [6].

This study attempts to obtain empirical evidence on the influence of the inherent international characteristics of CEOs on CSR disclosure activities in Indonesia. Thus, this paper contributes to the CSR literature and assisting the regulator or government to implement CSR-related policies. The research problem is whether the CEO's international characteristics influence CSR disclosure.

This study contributes to the development of CSR literature by examining the involvement of CEOs who have international characteristics in corporate CSR disclosure because of the need for corporate legitimacy in the social environment. This study also has implications for regulatory agencies and policymakers related to CSR because we assess the amount of disclosure by the company. We expect that there will be an output in the form of CSR reporting standards in accordance with the conditions of Indonesia.

\section{LITERATURE REVIEW AND HYPOTHESIS DEVELOPMENT}

\section{A. Literature Review}

\section{1) Stakeholder Theory}

As stated by the stakeholder theory, a company is an entity that operates for its benefit and the benefit of its stakeholders. In other words, the existence of an entity does not stand on its own but is supported by various parties, in this case, the stakeholders.

According to [7], basically, the stakeholders can control or possess the ability to influence the utilization of a company's economic resource; thus, it is critical for the company to fulfill a stakeholder's demand. Based on these explanations, stakeholder theory is basically related to the methods that companies use to position themselves against their stakeholders. Those methods heavily rely on the strategy used by the company; thus, the role of the CEO is critical.

\section{2) Legitimacy Theory}

The desire to legitimize the operation of the organization is one factor widely accepted by researchers as a motive behind the disclosure of social and environmental information [8]. Company operations often affect the individuals around them; thus, the company is part of the community. This phenomenon affects the existence of the company, where the existence of the company can be accepted by members of the community or vice versa, where the existence of the company can be impended if the company fails to adapt to the norms in the community. This success or failure of the company occurs because of the role of the community in giving permission to the company to carry out the production function; thus, the top management of the company attempts to adjust the activities to be in line with the values in the community [9].

The legitimacy theory is grounded on the social contract between a company and a community that receives the impact of its operations and the utilization of a company's economic resources. Theoretical legitimacy is considered something desired or sought after by companies from the community and something that the community provides to the company. Thus, based on legitimacy theory, social disclosure in CSR is critical because the community's contribution provides added value for the company, including the use of social resources.

\section{3) Human Capital Theory}

Human resources can influence top executives' ability to contribute to their company's strategy and performance. Human resources, defined as embedded resources in humans [10], refers to investments made by individuals in the form of education and training to increase skills. Individuals make choices about activities to increase productivity to maximize future income and realize psychological benefits [11]. 
The human resources possessed by top executives (i.e., skills, experience, and knowledge) are related to the ability of top management to gain access to resources that increase the likelihood that the strategies created are effective and efficient. Therefore, companies tend to choose high human resources. Human resources are divided into two types, namely, general and specific [10]. General human resources refer to quality and experience, such as education level, professional qualifications, and age, that is, factors that improve productivity. Individuals who have experience and achievements in the education sector signal future productivity because of their proven experience and education [12]. Furthermore, specific human resources refer to the accumulation of knowledge and skills required to perform a particular task. Knowledge and skills from specific human resources can affect performance such as industry-specific experience and special education-related business. An individual who has experience in the same industry as the company that recruited them tends to bring the knowledge and skills they have acquired in the industry to help them make strategic decisions as members of top management.

\section{B. Hypothesis Development}

\section{1) Experience of CEO Working Abroad and CSR}

According to [5], a CEO is a corporate leader that has a crucial role in a company's resource allocation and strategic decision-making. As a company leader, the CEO is responsible for managing the company in a manner that results in profits. CSR disclosure from companies in Indonesia is considered minimal because so far, CSR activities are considered by some CEOs in Indonesia to be activities that do not provide many benefits and result in reduced company profits. This perspective is also reinforced by the condition that there are still very limited number of Indonesian companies publish a sustainability report disclosing their CSR activities.

Overseas companies, especially in Europe and the US, believe that CSR provides benefits beyond charity or spending, that is, CSR has a positive impact on the country and the companies that implement it. In addition, the rate of CSR disclosure is higher in companies outside of Indonesia because companies consider CSR activities a means to gain legitimacy within a community so that they can maintain their existence. This phenomenon is observed in the survey conducted by the YCELP and CIESIN, which ranked countries outside of Indonesia, especially Europe and the United States, at the top for CSR activities disclosures.

The research on top management experience has been conducted by [13]; [14]; [15]. Although research on a CEO's international experience with CSR remains limited, one study [6] used a sample of 502 chief directors in United States' companies in 2004 and showed that the president director who has experience of working abroad had a positive effect on CSR disclosure. Thus, the hypotheses proposed for this study is as follows:

H1: The experience of a CEO working abroad has a positive effect on the disclosure level of CSR.

\section{2) Background of CEO Education Abroad and CSR}

Educational background reflects an individual's ability and cognitive skills. A high level of education is related to the ability to distinguish between various stimuli and a high capacity in processing information [16]. Educated individuals tend to engage in existing limitations, tolerate ambiguity, and demonstrate the ability of "integrative complexity" [17]. Furthermore, a high educational background consistently has consistently shown a relationship with the level of generating innovation in individuals ([18]; [19]; and [20]). Thus, it is expected that individuals with a good level of education can realize and accept the need for changes to the level of CSR disclosure.

Assuming that the level of education achieved abroad correlates with better cognitive abilities, the level of education achieved abroad is related to the ability to produce and apply creative solutions to various complex problems. The ability of cross-functional communication that they have is generally recognized as a critical factor to produce innovation and ideas in new ways ([21]; [22]) that will have a positive impact on CSR policies.

The second hypothesis examines the influence of foreign directors' educational backgrounds on the level of CSR disclosure. Some authors have examined this topic ([23]; [24]; [25]) and have demonstrated the impact of good education on companies. This study links the education of the principal directors and the level of CSR disclosure to the company. It is believed that a good education has implications for maximizing profits and company expansion on socioenvironmental aspects. Therefore, it will be notable to verify whether this belief is true and assess whether the directors who were educated abroad tend to express higher CSR practices.

$\mathrm{H} 2$ : CEO who possesses the experience of being educated abroad has a positive effect on the disclosure level of CSR.

\section{3) CEOs with foreign citizenship and CSR}

Citizenship is a source of knowledge about certain economic or regional conditions. A member of top management who is born and grows up abroad has valuable knowledge about the economy, market conditions, and institutions where they were born and aspects related to behavior, culture, and norms their country or region of origin. According to [26], this knowledge has substantial value when top management makes decisions regarding company strategies in certain countries or regions, especially regarding the company's international operations in general.

Much of the literature has focused on the international experience of corporate top management ([13]; [14]; [15]). By contrast, according to [26], national origin is also notable; however, the aspects of the background and international orientation of top management have been less studied. This assertion is supported by the statement of Caligiuri et al. (2004), that is, the scope of international attitudes of top management is incomplete if it focuses on only the international experience of top management.

According to Doctor (1990), all CEOs make decisions and plans that others will follow in the short and long term; then, they provide assignments to company members and coordinate various individual activities and related parts. The CEO also has the duty to monitor the functions and conditions of the companies they lead and be responsible for the final results. All CEOs also have relationships outside the corporate environment, they negotiate with other companies or governments and function as representatives of the organization to the public, in their country and in other countries. Therefore, CEOs in organizations that conduct international business and are familiar with national culture are a critical part of the external environment. CEOs must be 
able to act in a manner consistent with the diverse expectations, values, and laws of the country where they do business. Therefore, in this study, we expect that a foreign CEO will fulfill public expectations for high levels of CSR disclosure in accordance with the values and laws of the CEO's country of work, and this has been supported by various studies that demonstrated that public social and environment awareness have increased significantly ([27]; [28]). The same trend applies to nongovernmental organizations that advocate CSR for social and environmental awareness (e.g., Greenpeace, Indonesia Business Links).

H3: CEOs with foreign citizenship have a positive influence on the disclosure level of CSR.

\section{4) Control Variables}

This study uses three control variables, which have been widely used for research on CSR.

\section{a) Size}

The size of the company is often used to explain disclosure of CSR where larger companies are considered to have more resources than smaller companies. Therefore, larger companies have more facilities, financing, and human resources to create CSR disclosures. [29], [30], [31], and [32] have demonstrated that firm size influences the extent of disclosure of social responsibility.

\section{b) Profitability}

According to Hackston and Milne (1996), profitability is one of the factors that determines the management's freedom and flexibilities to disclose their social responsibility. The higher the company's level of profitability, the greater the opportunity for the management to prepare social and environmental disclosures. Research by [33] and [34] has demonstrated that profitable companies tend to engage more to social activities.

\section{c) Leverage}

[35] stated that the company's decision to disclose social information has implications for decreased expenditure on disclosure. Based on agency theory, the management of companies with a high level of leverage will reduce the disclosure of social responsibility so as not to become the focus of the debtholders. The results of [35]'s research show that leverage has a negative effect on CSR disclosure.

\section{RESEARCH METHOD}

\section{A. Data and Sample}

This study uses secondary data from the annual report and financial statements of manufacturing companies in 2016 obtained through IDX BEI or a company-owned website. The data in the annual report is used in conjunction with the CEO's international characteristics and any indicators that the GRI should disclose.

\section{Indonesia}

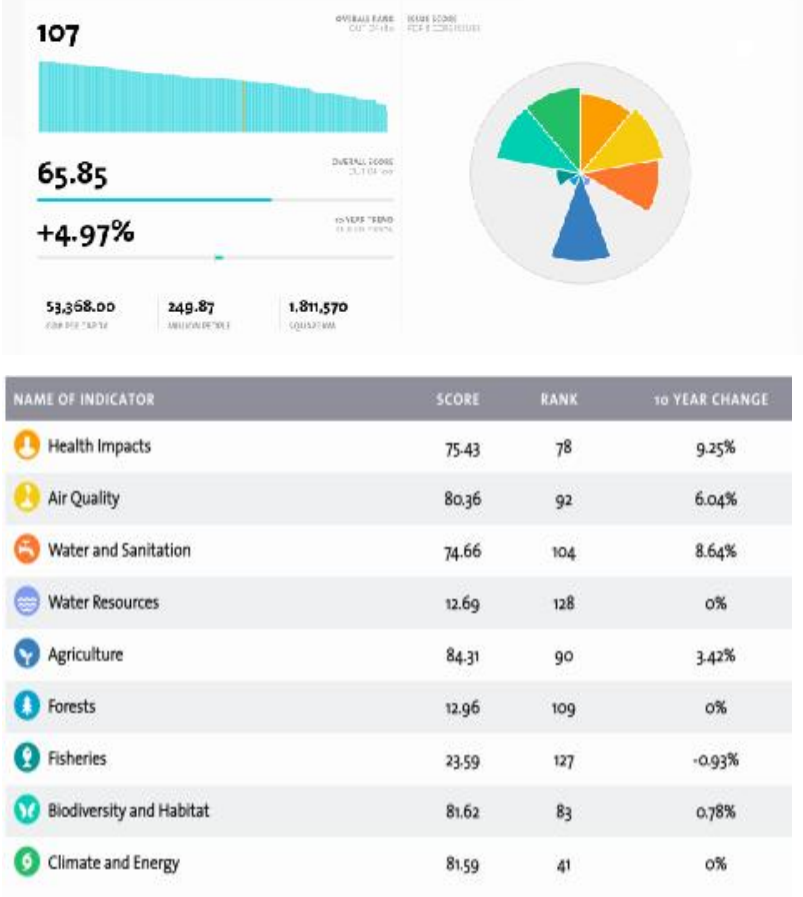

Fig. 1. Environmental Performance Index

The sample for this study is all listed manufacturing companies in on the Indonesia Stock Exchange in 2016. In accordance with the research conducted by [36], we use the cross section and time series data for the time period selection. Their research indicated that, in the same sample company, the positive effects of the two variables are weaker when the research is conducted using time series data. Thus, this study uses cross-section data to find strong associations between the dependent and independent variable. Cross-section data used for the research will be selected from manufacturing industry companies listed on the BEI in 2016 because the authors expect the contribution of this research to be through the use of data and the most current information. The justification for using cross-section data is also based on [6], that is, the evaluation is performed for CEOs who had tenure for at least 1 year and were thus in a position to influence the CSR activity and disclosure of their firm in the target year.

This study does not use the company's sustainability report as a base of CSR disclosure information because not all manufacturing industry companies release sustainability reports. In addition, the authors use other sources from the internet, such as Bloomberg and Thomson Reuters, to obtain the data used for the independent variables.

\section{B. Criteria for International Characteristics of the CEO}

Based on the EPI data released by the YCELP and DataDriven Yale and the CIESIN at Columbia University, in collaboration with the Samuel Family Foundation, the McCall MacBain Foundation, and the World Economic Forum, in 2018, Indonesia was ranked 107 out of 180 countries. Furthermore, in 2016, the United Nations released the 2015 Education Index in the 2016 Human Development Report. In the report, Indonesia was ranked 112 out of 188 countries. 
Based on those two sources of statistical data, this study uses the CEO characteristic criteria as follows:

- If the CEO has experience working abroad and citizenship in countries with an EPI rating greater than Indonesia's rating, the CEO fulfills this criterion and is included as part of the sample.

TABLE I. EDUCATION INDEX

\begin{tabular}{|l|l|l|l|l|}
\hline Rank & Country & $\begin{array}{l}\text { Education } \\
\text { Index }\end{array}$ & $\begin{array}{l}\text { Expected } \\
\text { Years of } \\
\text { Schooling }\end{array}$ & $\begin{array}{l}\text { Mean Years of } \\
\text { Schooling }\end{array}$ \\
\hline 112 & & 0.622 & 12.9 & 7.9 \\
& & & \\
\hline
\end{tabular}

- If the CEO has an educational background in countries with an Education Index rating greater than Indonesia's rating, the CEO fulfills this criterion and is included as part of the sample.

- If the CEO fulfills one or two of the aforementioned criteria, the CEO is included as part of the sample.

\section{Research Model}

The research model to test hypotheses in this study is as follows:

$\mathrm{CSR}_{\mathrm{n}}=\alpha+\beta_{1} \mathrm{EXP}_{\mathrm{it}}+\beta_{2} \mathrm{EDUC}_{\mathrm{it}}+\beta_{3} \mathrm{COUNTRY}_{\mathrm{it}}+$

$\beta_{4}$ LEVERAGE $_{\text {it }}+\beta_{5}$ ROA $_{\text {it }}+\beta_{6}$ SIZE $_{i t}+\varepsilon$

Where:

CSRit: Disclosure of CSR

$\alpha$ : Constant coefficients

$\beta_{1-6:}$ Regression coefficient of independent variables

EXP $_{\text {it }}$ : CEO with experience working abroad: 1; CEO with no experience working abroad: 0

EDUC $_{\mathrm{it}}$ : CEO with educational background abroad: 1; CEO with no educational background abroad: 0

COUNTRY $_{\text {it: }}$ CEO with foreign citizenship: 1; CEO with Indonesian citizenship: 0

Leverage $_{\text {it: }}$ : Debt to equity

$\mathrm{ROA}_{\mathrm{it}}$ : Return on asset

SIZE $_{\mathrm{it}}$ : Company size (ln total assets)

$\varepsilon$ : error

\section{RESUlT AND DISCUSSION}

\section{A. Statistic Descriptive}

Before presenting further statistical tests, the first step is a descriptive analysis performed by including all the variables of all the sample firms to determine the minimum, maximum, average, and standard deviation values of each variable. To obtain a general overview of the variable statistics, each variable in the sample is then calculated on average, standard deviation, minimum, and maximum. The presentation of descriptive statistics distinguishes between dummy variables and ratios. The dummy variable presents the percentage whose variable value is 1 of the entire variables so that the standard deviation presentation, minimum, and maximum values become irrelevant.

To overcome the outlier, this research uses a robust regression method. This method is a valuable tool for analyzing data influenced by the outlier so that a robust or resistance model is produced for the outlier. A resistance estimate is relatively unaffected by large changes in small parts of the data or small changes in large parts of the data.

The descriptive statistics of the variables used in the research is presented in Table II.

Based on the descriptive data in Table II, the dependent variable for CSR disclosure in 2016 has a minimum value of 0.054945 and a maximum value of 0.42857 , and the average value of CSRI in 2016 was 0.197017.

For experience variables, a CEO working abroad can be described because the 2016 sample companies that had a CEO with experience working abroad was as many as 47 companies, and the percentage was $33.81 \%$. Notably, the number of sample companies that did not have a CEO with experience working abroad was 92, and the percentage was $66.19 \%$. For CEO education background variables, in 2016, as many as $84(60.43 \%)$ companies had CEOs with an educational background abroad, and the number sample companies with CEOs with no education abroad was 55 (39.57\%). Finally, for CEO variables with foreign citizenship, in 2016, as many as $27(19.42 \%)$ firms were led by CEOs with foreign citizenship, and the number of sample companies not led by CEOs with foreign citizenship was 112 (80.58\%).

\section{B. Classic Assumption Test Results}

\section{1) Normality Test}

The data in this study is normally distributed, and this is shown with the value Prob> chi2 of 0.1770 , which is more than 0.05 (Table III).

\section{2) Multicollinearity Test} IV.

The results of the multicollinearity test are listed in Table

The results of multicollinearity test in Table IV show that this research model has been free from a multicollinearity problem. This status is indicated by the absence of a variable that has a variance inflation factor greater than 10 and because the tolerance value of each independent variable is below 1 .

\section{3) Heteroscedasticity Test}

The heteroskedasticity test in this research was performed by using the Breusch-Pagan method. Based on Table V, the value of the $p$ value is 0.2010 where > 0.05 ; thus, the regression model in this study has been free from the assumption of heteroscedasticity. In other words, the regression model in this study has fulfilled the assumption of homoscedasticity. 
TABLE II. EDUCATION INDEX

2016

\begin{tabular}{|c|c|c|c|c|c|}
\hline Variabel & $\mathbf{N}$ & Mean & Std Dev & Min. & Max. \\
\hline CSRDisclosure & 139 & 0.1970114 & 0.0699103 & 0.054945 & 0.428571 \\
\hline SIZE (000.000) & 139 & $9,198,551$ & $28,400,318$ & 40,195 & $295,646,000$ \\
\hline ROA & 139 & 0.0422988 & 0.0959622 & -0.4108549 & 0.3912743 \\
\hline Leverage & 139 & 0.2945481 & 0.4704945 & 0 & 4.747307 \\
\hline \multirow{2}{*}{ Variabel } & \multirow{2}{*}{$\mathbf{N}$} & \multicolumn{2}{|c|}{ Frequency } & \multicolumn{2}{|c|}{ Percentage } \\
\hline & & $\mathbf{0}$ & 1 & $\mathbf{0}$ & 1 \\
\hline EXP & 139 & 92 & 47 & $66.19 \%$ & $33.81 \%$ \\
\hline EDUC & 139 & 55 & 84 & $39.57 \%$ & $60.43 \%$ \\
\hline COUNTRY & 139 & 112 & 27 & $80.58 \%$ & $19.42 \%$ \\
\hline
\end{tabular}

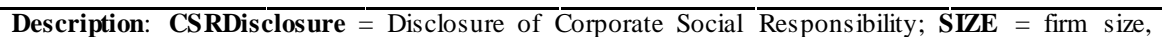
measured by the natural logarithm of total assets; ROA = ratio of total as sets, measured by net income / total as sets $; \mathbf{L E V}=$ Leverage, measured by debt / total assets $; \mathbf{E X P}=\mathrm{CEO}$ who has experience working abroad; EDUC = CEO who has an educational background abroad; COUNTRY = CEO with foreign citizenship.

\begin{tabular}{|c|c|c|c|c|c|c|}
\hline \multirow[b]{3}{*}{ Variable } & \multicolumn{3}{|c|}{ NORMALITY TEST } & & & \\
\hline & \multicolumn{4}{|c|}{ Skewness/Kurtosis tests for Normality } & & \\
\hline & $\mathrm{Obs}$ & $\operatorname{Pr}($ Skewness) & $\operatorname{Pr}($ Kurtosis) & $\operatorname{adj}$ & $\operatorname{chi2}(2)$ & Prob>chi 2 \\
\hline res & 139 & 0.0683 & 0.7806 & & 3.46 & 0.1770 \\
\hline
\end{tabular}

\section{4) Heteroscedasticity Test}

The heteroskedasticity test in this research was performed by using the Breusch-Pagan method. Based on Table V, the value of the $p$ value is 0.2010 where > 0.05 ; thus, the regression model in this study has been free from the assumption of heteroscedasticity. In other words, the regression model in this study has fulfilled the assumption of homoscedasticity.

\section{Regression Result Analysis}

Based on the results shown in Table VI, we conclude that the models used in this study are valid to be used because they have a probability value of an $\mathrm{F}$ statistic below the critical level of $1 \%$ such that the model used in this study is significant at $99 \%$ confidence level. This result indicates that the independent variables and control variables simulta-neously affect the variation of the dependent variable significantly.

Table VI presents the results of the determination coefficient test on the research model used in this study. The coefficient of determination test is assessed through Adjusted R2. The greater the value of Adjusted R2, the greater the ability of the independent variables to explain the dependent variable (CSR disclosure). The value of Adjusted R-squared is 0.3862 , as explained in the table VI. This means that the variability that can be explained by the independent variable and the control variable to the dependent variables is $38.62 \%$.

\section{Discussion}

\section{1) CEO's Experience Working Ahead}

A CEO's working experience abroad in this study was measured based on whether the CEO of a manufacturing industry company has worked for an overseas company. This study follows [6], who did not use different treatments for the length of time the CEO worked abroad. This decision was based on the limited information related to the length of CEO's working experience abroad disclosed in the company's annual report. Thus, there are no differences in the assessment for the CEOs with 1-year or 6 months of experience of working abroad.

TABLE IV. Multicolinearity Test

\begin{tabular}{|l|c|c|}
\hline \multirow{2}{*}{ Variabel } & Variance Inflation Factor $($ VIF $)$ \\
\cline { 2 - 3 } & VIF & 1/VIF \\
\hline EXP & 1.97 & 0.507693 \\
\hline EDUC & 1.31 & 0.762955 \\
\hline COUNTRY & 1.81 & 0.552242 \\
\hline SIZE & 1.11 & 0.902171 \\
\hline ROA & 1.20 & 0.835801 \\
\hline LEVERAGE & 1.11 & 0.898474 \\
\hline
\end{tabular}

The results of the statistical analysis of the CEO's experience working abroad variable show that CEO experience is positive and significantly affected the CSR disclosure. Positive research results on the CEO's experience working abroad indicate that the CEO's experience working abroad contributes to the CSR disclosure in Indonesia's manufacturing companies; additionally, it shows that the CEO has implemented the CSR activities that they conducted before while working abroad in the companies they lead in Indonesia; thus, the CEO's experience working abroad influences CSR disclosure.

The results of this study are in accordance with stakeholder theory, that is, the company does not operate only on the basis of its interests but also provides benefits to its stakeholders. This research is also in line with the legitimacy theory, where the top management of companies will attempt to conform with organizational actions and values in the relevant general or public society [9] because the community 
has given permission to the companies to carry out various operations, for example, using human resources and natural resources, may cause various problems society and the environment, such as social problems, pollution, and waste resources (Hackston \& Milne, 1996). Business can be performed by conducting socialization and communication on the environmental and social impacts of the economic activities of the entity with the concerned surrounding community. This notion is also in line with the understanding that the CEO of the company aims to improve her or his company's reputation in front of stakeholders, which makes the company in accordance with the stakeholder's expectations and norms; thus, ultimately, the support of stakeholders for the company is greater, and the company has sustainable competitiveness.

These results are similar to studies conducted by [6], which used a sample of companies in the United States, where they also found a positive relationship between CEO's working experience overseas and CSR disclosures. The result might be because of the reason that a CEO with working experience overseas is expected to reveal her or his activities related to the CSR of the companies they lead in accordance with their working experience with the motivation to maintain their existence while still working in overseas companies. This research is also able to test the consistency of the results of previous studies when using a sample of companies in the manufacturing industry in Indonesia in 2016.

\section{2) CEO's Education Background Aboard}

To obtain the result of the second hypotheses, we test the impact of the CEOs' educational backgrounds abroad on CSR disclosure activities. According to the results of the statistical tests for CEOs with educational backgrounds abroad, the CEO's educational background is positive and significantly affected the CSR disclosure. Positive results on CEO's experience variables working abroad indicate that the CEO's overseas educational background influences CSR disclosure policies in manufacturing companies in Indonesia. This result shows that CEOs with better cognitive abilities are able to produce and implement CSR activities in companies they lead and able to contribute to the CSR activities disclosure. CEOs with an overseas education background with a good cognitive level are able to implement their knowledge or their experience of CSR activities they have learned and experienced during their education abroad.

TABLE V. HETEROSCEDASTICITY TEST

Breusch-Pagan / Cook-Weisberg test for heteroskedasticity

Ho: Constant variance

Variables: fitted values of CSRDisclosure

\section{$\operatorname{chi2}(1)=1.64$}

Prob $>$ chi2 $=0.2010$

The results of this are in line with the legitimacy theory, in which top management is able to adjust the values in society and the public that are relevant to organizational actions [9] in the form of CSR activities disclosure. The results are also in line with the theory of human capital which refers to the dimension of education indicated by the relationship between the CEO with educational backgrounds abroad on the CSR disclosure for companies in the manufacturing industry in Indonesia.
The results of this research support the research related to this hypothesis ([23]; [24]; [25]). These results indicate that a good education has implications om maximizing profits and company expansion into socioenvironmental aspects. This research was also able to test the consistency of the results of previous studies when using company samples in the manufacturing industry sector in Indonesia in 2016.

\section{3) $C E O$ with foreign citizenship}

The testing of the third hypothesis in this study is to examine the influence of a CEO with foreign citizenship on CSR disclosure. Based on the statistical analysis test for CEO with foreign citizenship, the results indicated that a CEO with foreign citizenship did not affect CSR disclosure. However, the direction of the coefficient shows a negative value, and this indicates that a CEO with foreign citizenship has a negative effect on CSR disclosure. The argument that can be used to explain this is as follows: CEOs with foreign citizenship working for companies in Indonesia do not really consider the issues related to environmental and social topics as a critical issue that should be disclosed in their annual reports; additionally, these CEOs have not been able to act in a consistent and fully compliant manner with the values, expectations, and laws in Indonesia because the presence of CEOs with foreign citizenship is expected to be able to fulfill public expectations for the level of high disclosure of CSR in accordance with the values and laws in Indonesia.

The results of this study contradict the hypothesis 3 proposed in this study, that is, the CEO with foreign citizenship will significantly affect the disclosure of CSR activities. Our result is in line with [37]'s study, which found no relationship between CEO nationality and CSR performance. Non-significant research results are suspected because the proportion of CEOs with foreign citizenship in Indonesia is small. Furthermore, according to [38], companies should be able to observe the benefits of legitimacy from their stakeholders, which are typically based on the home market (market place of operation) and can provide a high existence in the long run. This phenomenon is not proven in this third hypothesis, which means that CEOs with foreign citizenship cannot take advantage of these benefits; thus, the results of this study are not successful in supporting the legitimacy theory. The result may be because the CEO with foreign citizenship in Indonesia has not considered social and environmental criteria.

\section{4) Control Variables}

a) Size

The results of this research support the studies that have demonstrated that the greater the firm, the greater the initiative to conduct and disclose CSR activities, and according to [29], large-sized companies were most highlighted by the community; thus, the CSR disclosure may act as a political cost reduction. Research conducted by [30] presents evidence about the factors that influence the CSR disclosure of companies in Portugal and concludes that firm size has positive effects on CSR disclosure. Consistent with the result depicted in Table VI, [29], [32], and [31] also found a positive influence between firm size and CSR disclosure. 
TABLE VI. REGRESSION RESULT

\begin{tabular}{|c|c|c|c|c|}
\hline Variabel & Pred & Coef & Prob & Sig \\
\hline EXP & + & 0.0215776 & $\overline{0.063}$ & * \\
\hline EDUC & + & 0.0159365 & 0.075 & $* *$ \\
\hline COUNTRY & + & -0.0194776 & 0.113 & \\
\hline SIZE & + & 0.0227709 & 0.000 & $* * *$ \\
\hline ROA & + & 0.0411597 & 0.228 & \\
\hline LEVERAGE & - & -0.012225 & 0.014 & $* *$ \\
\hline cons & & -0.4564144 & 0.000 & \\
\hline $\begin{array}{l}\quad \text { (Number } \\
\text { Observation) }\end{array}$ & & \multicolumn{3}{|c|}{139} \\
\hline Adjusteds R-Squ & & \multicolumn{3}{|c|}{0.3862} \\
\hline Prob (F-Statistic & & \multicolumn{3}{|c|}{0.0000} \\
\hline
\end{tabular}

Description: CSRDisclosure $=$ Disclosure of Corporate Social Responsibility; SIZE = firm size, measured by the natural logarithm of total assets; ROA = ratio of total assets, measured by net income / total assets; LEV = Leverage, measured by debt / total assets; EXP $=$ CEO who has experience working abroad; EDUC = CEO who has an educational background abroad; COUNTRY $=\mathrm{CEO}$ with foreign citizenship.

\section{b) Profitability}

This study also supports research conducted by Hackson and Milne (1996), who found no evidence of an influence between corporate profitability and CSR disclosure. This study indicates that companies with a high level of profitability that have sufficient resources to fund their social and environmental activities are not necessarily going to allocate their funds to social and environmental activities. This research shows that companies with more profitabilities will disclose CSR information to show their concern for the community and is thus not in line with the legitimacy theory.

\section{c) Leverage}

The results of this study successfully support [35], who states that companies with high leverage levels will disclose less CSR information. The company will attempt to report the higher current profit because the higher the level of corporate leverage, the higher the likelihood that the company will violate the credit agreement. Thus, for reported earnings to be higher, the manager reduces other costs including costs to disclose CSR information [35].

\section{CONCLUSION, LimitATIONS, AND SUGgESTIONS}

\section{A. Conclusions}

Based on the results of the aforementioned data analysis and discussion, the conclusions based on the results of this study are as follows:

- The CEO's experience working abroad has associations with higher CSR disclosure to companies in the manufacturing industry in Indonesia. This conclusion is because CEOs who have experience working overseas were predicted to disclose the CSR activities of the company they lead in a manner consistent with their experience working overseas with the motivation to maintain their performance while continuing to work in companies abroad.

- The CEO's educational background abroad has associations with higher CSR disclosure to companies in manufacturing industries in Indonesia. This conclusion indicates that CEOs with better cognitive abilities are able to generate and implement CSR activities in the companies they lead to influence CSR activity disclosure, and CEOs with an educational background abroad are able to implement their knowledge or experience regarding their CSR activities have been learned and experienced during their education abroad.

- CEOs with foreign citizenship in Indonesia have not wholly considered the social and environmental criteria. This might occur because foreign CEOs of firms in Indonesia, in general, do not consider issues related to environmental and social concerns as critical issues that should be extensively disclosed in the company's annual reports, and CEOs have not been able to act consistently and fully adhere to the values, expectations, and laws in Indonesia.

\section{B. Limitations}

This research has limitations, and the most notable are as follows:

- The use of research samples from only companies in the manufacturing industry may not be able to comprehensively describe the practice conditions of actual CSR disclosure in Indonesia.

- The value of CSR disclosure in this study cannot be used as a reference for further research because there is no standard provision in a standard setting; thus, there is a risk of subjectivity in the measurement of the CSR disclosure index.

- The company from which the CEO had worked was not treated differently in this study.

- The length of experience of the CEOs' work abroad is not considered in determining the sample of this study because of the limited information available.

\section{Suggestions}

From the conclusions and limitations in this study, we provide several suggestions for further research:

- Further research could take samples from all listed industries so that CSR disclosure can better reflect the actual conditions of disclosure practices.

- Further research should expand the observation period by using more sample quantities and longer data periods; thus, the consistency of the results of this study could be tested.

- Further research is expected to provide different and more specific assessments for a CEO's work experience abroad, educational background, and foreign nationality and provide different and more specific assessments on the countries where the CEOs previously worked, the countries where they were educated, and their country of origin.

- Further research should use an annual report and sustainability reports to assess CSR disclosure.

- Further research could be more specific regarding criteria for an overseas CEO, such as the length of work overseas.

\section{REFERENCES}

[1] S. Utama, "An evaluation of support infrastructures for corporate responsibility reporting in Indonesia," Asian Bus. Manage., vol. 10, pp. 405-424, 2011. 
[2] H. K. M. Kalangit, "Konsep Corporate Social Responsibility, Pengaturan dan Pelaksanaannya di Indonesia," Bogor: Lingkar Studi CSR/A+ CSR Indonesia, 2009. https://www.slideshare.net/KingHBen gawan/20090202132726-a.

[3] A. Sutedi, Buku Pintar Hukum Perseroan Terbatas, Jakarta: Raih Asa Sukses (Penebar Swadaya grup), 2015.

[4] V. M. Strike, J. Gao, and P. Bansal, "Being good while being bad: Social responsibility and the international diversification of US firms," J. Int. Bus. Stud., vol. 37, pp. 850-862, 2006.

[5] L. T. Hosmer, "The importance of strategic leadership," J. Bus. Strat., vol. 3, pp. 47-58, 1982

[6] D. J. Slater and H. R. Dixon-Fowler, "CEO international assignment experience and corporate social performance,” J. Bus. Eth., Vol. 89, pp. 473-489, 2009.

[7] I. Ghozali and A. Chariri, Teori Akuntansi. Semarang: Badan Penerbit Universitas Diponogoro, 2007.

[8] C. Deegan, "Introduction: The legitimising effect of social and environmental disclosures-a theoretical foundation," Account. Auditing Accoun. J., vol. 15, pp. 282-311, 2002.

[9] J. Dowling and J. Pfeffer, "Organizational legitimacy: Social values and organizational behavior," Pac. Sociol. Rev., vol. 18, pp. 122-136, 1975.

[10] G. S. Becker, Human capital, New York: Columbia University Press, 1964

[11] J. Gimeno, T. B. Folta, A. C. Cooper, and C. Y. Woo, "Survival of the fittest? Entrepreneurial human capital and the persistence of underperforming firms," Admin. Sci. Q., vol. 42, pp. 750-783, 1977.

[12] D. Laing, and C. Weir, "Corporate performance and the influence of human capital characteristics on executive compensation in the UK," Pers. Rev., vol: 28, pp. 28-40, 1999.

[13] R. B. Sambharya, "Foreign experience of top management teams and international diversification strategies of U.S. multinational corporations," Strat. Manag. J., vol. 17, pp. 739-746, 1996.

[14] M. A. Carpenter, W. G. Sanders, and H. B. Gregersen, "Bundling human capital with organizational context: The impact of international assignment experience on multinational firm performance and CEO pay," Acad. Manage. J., vol. 44, pp. 493-511, 2001.

[15] M. A. Carpenter and J. W. Fredrickson, "Top management teams, global strategic posture and the moderating role of uncertainty," Acad. Manage. J., vol. 44, pp. 533-545, 2001.

[16] H. M. Schroder, M. J. Driver, and S. Steufert, Human information processing, New York: Holt Rinehart and Winston, 1967.

[17] M. J. Dollinger, "Environmental boundary spanning and information processing effects on organizational performance," Acad. Manage. J., vol. 27, pp. 351-368, 1984.

[18] M. Becker, "Sociometric location and innovativeness," American Soc. Rev., vol. 35, pp. 267-304, 1970.

[19] E. Rogers and F. Shoemakers, Communication of innovations, New York: Basic Books, 1971

[20] J. R. Kimberly and M. J. Evanisko, "Organizational innovation: The influence of individual, organizational, and contextual factors on hospital adoption of technological and administrative innovations," Acad. Manag. J., vol. 24, pp. 689-713, 1981.

[21] R. Rothwell and Z. Walter, Reindustrialization and technology, UK Longman, Essex, 1985.

[22] P. Shrivastava and W. Souder, "Phase transfer models for technological innovation,” Adv. Strat. Manage., vol. 3, pp. 135-147, 1985.
[23] M. Useem and J. Karabel, "Pathways to Top Corporate Management," Am. Soc. Rev., vol. 51, pp. 184-200, 1986.

[24] D. Palmer and B. M. Barber, "Challengers, elites, and owning families: A social class theory of corporate acquisitions in the 1960s," Admin. Sci. Q., vol. 46, pp. 87-120, 2001.

[25] S. Chikh and J. -Y. Filbien, "Acquisitions and CEO power: Evidences from French networks,” J. Corp. Finan., vol. 17, pp. 1221-1236, 2011.

[26] S. Nielsen and B. B. Nielsen, "Why do firms employ foreigners on their top management team? An exploration of strategic fit, human capital and attraction selection attrition perspectives," Int. J. Cross Cult. Manage., vol. 10, pp. 195-209, 2010.

[27] M. Vagasi, "Sustainable consumption and environmentally-conscious consumer behavior," Hung. J. Market. Manage., vol. 34, pp. 9-44, 2000.

[28] L. Mastny, "Purchasing for people and the planet," Worldwatch Institute (Ed.), State of the World 2004: Special Focus: The Consumer Society, New York: Norton \& Norton, pp. 122-141, 2004.

[29] E. R. Sembiring, "Karakteristik Perusahaan dan Pengungkapan Tanggung Jawab Sosial: Study Empiris pada Perusahaan yang Tercatat di Bursa Efek Jakarta," Simposium Nasional Akuntansi 8, Solo, 2005.

[30] M. C. Branco and L. L. Rodrigues, "Factors influencing social responsibility disclosure by Portuguese companies," J. Bus. Ethics, vol. 83, pp. 685-701, 2008

[31] N. Machmud and D. D. Chaerul, "Pengaruh Struktur Kepemilikan Terhadap Luas Pengungkapan Tanggung Jawab Sosial (CSR Disclosure) Pada Laporan Tahunan Perusahaan: Studi Empiris Pada Perusahaan Publik Yang Tercatat di Bursa Efek Indonesia Tahun 2006," Simposium Nasional Akuntansi 11, Pontianak, 2008.

[32] C. Reverte, "Determinants of Corporate Social Responsibility Disclosure Rating by Spanish Listed Firms," J. Bus. Ethics, vol. 88, pp. 351-366, 2008.

[33] R. W. Roberts, "Determinants of corporate social responsibility disclosure: an application of stakeholder theory," Account. Organizations Soc., vol. 17, pp. 595-612, 1992.

[34] L. L. Eng and Y. T. Mak, "Corporate governance and voluntary disclosure," J. Account. Pub. Pol., vol. 22, pp. 325-345, 2003

[35] A. Belkaoui and P. G. Karpik, "Determinants of the corporate decision to disclose social information," Account. Audit. Account., vol. 2, pp. 36-51, 1989.

[36] E. Nelling and W. Elizabeth, "Corporate social responsibility and financial performance: The "virtuous circle" revisited," Quant. Financ. Account., vol. 32, pp. 197-209, 2009.

[37] S. K. Huang, "The Impact of CEO Characteristics on Corporate Sustainable Development," Corporate Soc. Responsibility Env. Manage., Wiley Online Library, 2012. http://doi.org/10.1002/csr.1 295.

[38] R. Barkemeyer, "Legitimacy as a Key Driver and Determinant of CSR in Developing Countries," The 2007 Marie Curie Summer School on Earth System Governance, University of St Andrews \& Sustainable Development Research Centre (SDRC) School of Management, Amsterdam, 2007.

[39] YCELP and CIESIN, Environmental Performance Index, 2015. www.epi.yale.edu.

[40] Human Development Report, Education Index, 2015. www.hdr.und p.org/en/content/education-index.

[41] N. Athanassiouand and D. Nigh, "The impact of the top management team' $\mathrm{s}$ international business experience on the firm' $\mathrm{s}$ internationalization: Social networks at work," Manage. Int. Rev., vol.42, pp.157-181, 2002 